\title{
Editorial
}

\section{Person-Patient-Family-Community Centered Care Semakin Penting}

\author{
ADI UTARINI ${ }^{1}$ \\ 1Departemen Kebijakan dan Manajemen Kesehatan, Fakultas Kedokteran, Kesehatan Masyarakat dan Keperawatan UGM \\ Email korespondensi: adiutarini@ugm.ac.id
}

Situasi pandemi memberikan ancaman serius dalam pemberian pelayanan individual, terutama bagi pasien dengan infeksi virus Corona yang dirawat inap di rumah sakit. Aspek medis (diagnosis dan pengobatan) yang merupakan subtansi utama pelayanan masih menimbulkan tantangan dalam penatalaksanaan pasien dengan infeksi virus Corona. Namun pada situasi yang kompleks ini, pemberian pelayanan kesehatan yang berorientasi pada kebutuhan individual setiap manusiapasien justru menjadi semakin penting. Setiap orang (termasuk pasien) membutuhkan dukungan yang lebih besar dan berarti dari keluarga dan masyarakat, serta tenaga kesehatan.

Beberapa istilah sering digunakan dan memiliki makna, prinsip dan aktivitas yang berbeda, namun tumpang tindih atau merupakan suatu kontinum: person-centered care, patientcentered care dan family-centered care. Starfield (2011) misalnya, memandang setiap orang sebagai manusia seutuhnya dalam person-centered care. Berbeda dengan patient-centered care, seperti yang digunakan dalam standar nasional akreditasi rumah sakit (KARS, 2019), yang bersifat sesaat dari perspektif waktu ketika sedang dirawat sebagai pasien. Family-centered care menekankan pada dukungan yang dapat diberikan keluarga (atau bahkan bisa saja orang lain yang berperan seperti keluarga) kepada pasien, terutama ketika orang-pasien tersebut sedang berada dalam keadaan yang tidak memungkinkan untuk mengambil keputusan, seperti ketika di ruang rawat intensif. Partisipasi keluarga dapat dilakukan dengan cara yang mendorong keluarga, pasien dan tim pelayanan kesehatan berkolaborasi (Hart, Turnbull, Oppenheim, \& Courtright, 2020). Ketiga konsep tersebut tidak lagi memadai pada situasi pandemi ini. Community-centered care yang semula memberikan konotasi awal yang terbatas, lekat dengan dimensi mutu akses, keadilan, dan fasilitas kesehatan primer (Morris, 2019) menjadi sangat penting dalam memberikan pelayanan kesehatan di rumah sakit, yang dapat terdampak secara langsung dari perilaku masyarakat.

\section{Tantangan person- hingga community-centered care di} masa pandemi

The Health Foundation di Inggris (2016) mengemukakan empat prinsip penting dalam kerangka person-centered care, meliputi: (1) memperlakukan seseorang secara bermartabat, menghargai dengan penuh kasih sayang; (2) Memberikan pelayanan, asuhan atau pengobatan yang terkoordinasi; (3) Memberikan pelayanan, dukungan atau pengobatan sesuai kebutuhan individu; dan (4) Mendukung upaya seseorang untuk mengenali, mengembangkan kekuatan dan kemampuannya untuk hidup secara mandiri dan berarti. Nilai-nilai ini merupakan nilai-nilai yang universal dalam pemberian pelayanan kesehatan, terlepas dari konsep yang digunakan, baik person-patient-family-community centered. Pada prakteknya, komunikasi yang terbuka, pemberian pelayanan multidisipliner dan terkoordinasi merupakan strategi sekaligus tantangan yang utama.

Berbagai tantangan dihadapi pada masa pandemi. Bagi pasien yang dirawat di rumah sakit, komunikasi tenaga kesehatan dengan individual pasien tidak lagi dapat menggunakan cara-cara yang biasa dilakukan. Strategi komunikasi menjadi sangat berbeda ketika berhadapan dengan pasien terinfeksi Coronavirus. Ketidakhadiran keluarga (seperti ketika diisolasi misalnya) justru dapat menimbulkan tekanan bagi pasien oleh karena menempatkan pasien (terutama yang secara klinis ringan atau sedang) dalam posisi sentral untuk memberikan informasi yang tepat kepada keluarga dan masyarakat di lingkungan tinggalnya. Pasien dapat menjadi tumpuan komunikasi berbagai pihak, bukan sebaliknya, sebagai pihak yang memerlukan dukungan keluarga dan masyarakat sekitarnya. Selama dirawat atau ketika kembali ke masyarakat, stigma yang tinggi di masyarakat dapat menjadi sumber kepanikan bagi pasien dan keluarganya. Beberapa fenomena di masyarakat mengisyaratkan bahwa situasi di atas tidak terkelola dengan baik, sehingga dampaknya semakin berat terhadap pasien dan keluarganya.

\section{Strategi baru yang perlu dikembangkan}

Kebutuhan akan pelayanan kesehatan yang melibatkan pasien, keluarga dan masyarakat menjadi semakin besar dan penting dalam situasi pandemi yang banyak menimbulkan keterbatasan sumber daya. Sementara protokol keselamatan pasien-tenaga kesehatan tetap pula harus diterapkan secara ketat pada situasi apapun. Oleh karena itu, diperlukan pengembangan strategi baru.

The International Society for Quality in Healtcare (ISQua) dalam editorial jurnalnya menyarankan lima strategi untuk melakukan pelibatan pasien, keluarga dan masyarakat (Editorial, 2020). Strategi tersebut meliputi:

- Pasien-keluarga-masyarakat bersama-sama dengan tenaga kesehatan menghasilkan solusi untuk 
pencegahan dan penatalaksanaan mandiri (selfmanagement). Komunikasi dilakukan secara transparan dan frekuensi ditingkatkan.

- Membantu mengidentifikasi, mengembangkan dan mensosialisasikan tools yang bermanfaat untuk membantu penatalaksanaan mandiri.

- Mengembangkan kemitraan antar pasien-keluargamasyarakat yang memiliki pengalaman dan dapat membantu orang lain.

- Memberikan saran bagi pimpinan untuk menguatkan strategi person-centredness selama pandemi.

- Menilai keadilan dalam pemberian pelayanan dan keselamatan pasien.

- Mengoptimalkan kebijakan visitasi dengan tetap mematuhi protokol kesehatan dan memanfaatkan media elektronik yang dapat digunakan untuk berkomunikasi dengan pasien-keluarga.
Strategi yang serupa juga dapat dikembangkan untuk tenaga kesehatan, baik ketika memberikan pelayanan yang terbaik kepada pasien maupun saat tenaga kesehatan harus mengalami peran sebagai pasien yang dirawat.

\section{Referensi}

Editorial. 2020. COVID-19: Patient Safety and Quality Improvement Skills to Deploy During the Surge. International Journal for Quality in Health Care, pp. 1-3. doi: 10.1093/intqhe/mzaao5o.

Hart, J.L., Turnbull, A.E., Oppenheim, M.O., \& Courtright, K.R. 2020. Family-Centered Care During the COVID-19 Era. Journal of Pain and Symptoms Management, 60 (2). Pp. e93-97.

Komisi Akreditasi Rumah Sakit. 2019. Standar Nasional Akreditasi Rumah Sakit. Edisi 1.1. Jakarta Indonesia: Komisi Akreditasi Rumah Sakit.

Morris, J.E. 2019. When "Patient-Centered" is Not Enough: A Call for Community-Centered Medicine. Ann Fam Med, 17: 82-84. https://doi.org/10.1370/afm.2335.

The Health Foundation. 2016. Person-centred Care Made Simple: What Everyone Should Know About Person-centred Care. London UK: The Health Foundation. 